\title{
Analisis Faktor-Faktor Meal Experience dalam Menciptakan Perilaku Konsumen Pasca Pembelian di Jubilare Dine and Wine Bandung
}

\author{
Ridwan Iskandar*1, Wishnu Wardhana ${ }^{2}$ \\ Sekolah Tinggi Pariwisata Bandung, Indonesia ${ }^{1,2}$ \\ Email: ridwaniskandar@stp-bandung.ac.id
}

\begin{abstract}
Restaurant and cafe industry competition is getting tougher. Implementation of the strategy is not right, causing not guaranteed of loyal consumers. When loyalty is difficult to form, at least marketers should pay attention to post purchase consumer behaviour. Consumers relate to a product, there are important elements involved in this interaction process, namely the consumer experience. Therefore, marketers should be able to pack the elements that can be controlled by the marketer that can create a positive meal experience. The presence of the stimuli provided by the organizer restaurant / cafe to create a memorable meal experience in order to stimulate the post purchase behaviour of consumers, the formulation of the problem and the purpose of this study is: How meal experience gained consumers restaurant / cafe. How consumer behaviour and how the influence of post purchase experience meal consisting of food and drinks, atmosphere, cleanliness, service levels and prices obtained by the consumer in the creation of post purchase consumer behaviour. With 110 respondents, researchers used a non-random sampling technique that is accidental sampling in selecting samples and processed using computer software SPSS 17.00. Based on the results of the correlation matrix between the sub variables meal experience of the post purchase behaviour obtained correlation results sequentially, namely, food and beverages (0.77), atmosphere (0.68), hygiene (0.65), service level (0.72) and the price (0.75). Effect of meal experience of the post purchase behaviour has a very strong relationship, which with a correlation coefficient of 0.764 , this shows that the meal experience. is able to make a positive contribution then post-purchase behaviour will tend to be positive anyway.
\end{abstract}

Keywords: Meal experience, Consumer behavior, Post purchase

\begin{abstract}
Abstrak
Persaingan industri restoran dan kafe semakin ketat. Implementasi strategi yang tidak tepat, menyebabkan konsumen tidak loyal. Ketika kesetiaan sulit dibentuk, setidaknya pemasar harus memperhatikan perilaku konsumen pasca pembelian. Konsumen berhubungan dengan suatu produk, ada elemen penting yang terlibat dalam proses interaksi ini, yaitu pengalaman konsumen. Oleh karena itu, pemasar harus dapat mengemas elemen-elemen yang dapat dikontrol oleh pemasar yang dapat menciptakan pengalaman makan yang positif. Kehadiran rangsangan yang diberikan oleh penyelenggara restoran / kafe untuk menciptakan pengalaman makan yang berkesan dalam rangka merangsang perilaku pasca pembelian konsumen, rumusan masalah dan tujuan dari penelitian ini adalah: Bagaimana pengalaman makan diperoleh konsumen restoran / kafe . Bagaimana perilaku konsumen dan bagaimana pengaruh pengalaman makan pasca pembelian yang terdiri dari makanan dan minuman, suasana kebersihan, tingkat layanan dan harga yang diperoleh oleh konsumen dalam penciptaan perilaku konsumen pasca pembelian. Dengan 110 responden, peneliti menggunakan teknik pengambilan sampel non-acak yaitu accidental sampling dalam memilih sampel dan diproses menggunakan perangkat lunak komputer SPSS 17.00. Berdasarkan hasil matriks korelasi antara sub variabel pengalaman makan pasca perilaku pembelian diperoleh hasil korelasi secara berurutan, yaitu makanan dan minuman $(0,77)$, atmosfer $(0,68)$, kebersihan $(0,65)$, tingkat layanan $(0,72)$ dan harga $(0,75)$. Pengaruh pengalaman makan dari perilaku pasca pembelian memiliki hubungan yang sangat kuat, dimana dengan koefisien korelasi sebesar 0,764, ini menunjukkan bahwa pengalaman makan. mampu memberikan kontribusi positif maka perilaku pasca pembelian akan cenderung positif pula.
\end{abstract}

Kata kunci: Pengalaman makan, Perilaku konsumen, Pembelian pasca

* Corresponding author

Received: August 03, 2017; Revised: November 09, 2017; Accepted: December 21, 2017 


\section{A. PENDAHULUAN}

Kota Bandung merupakan kota yang menempati urutan pertama tingkat kunjungan wisata kuliner di daerah Jawa Barat. Dari potensi inilah para pelaku bisnis berlomba- lomba membuka usaha dibidang kuliner, sehingga Bandung memiliki berbagai macam jenis restoran mulai dari fine dining, coffe shop, dan specility restaurant. Dapat dipastikan bahwa restoran yang menyediakan menu sesuai pesanan (a la carte), saling berlomba dan bersaing dalam menyajikan kepuasan kepada para pelanggannya. Walaupun kepuasan pelanggan adalah salah satu tujuan utama, namun ada sisi lain yang seringkali membebani pikiran para pengusaha restoran.

Hal tersebut secara sederhana disampaikan dalam pertanyaan sebagai berikut: kenapa diantara menu yang dijual ada yang lads namun tidak memberikan keuntungan yang signifikan, tetapi ada menu yang kurang lads namun memberikan keuntungan yang sangat signifikan. Salah satu upaya yang dilakukan untuk menyiasati kenyataan ini adalah para pengusaha tetap menyajikan menu tersebut sebagai menu khas restorannya, walupun keuntungan yang diperoleh tidak signifikan. Disisi lain prinsip bahwa penjualan harus dapat memberikan keuntungan yang signifikan tetap dikedepankan, agar kegiatan usaha dapat berkembang dengan baik Untuk mengatasi masalah inilah diperlukan langkah-_ langkah penting menyusun strategi dan desain pemasaran dengan memperhatikan setiap perubahan yang terjadi.

Untuk mempertahankan konsumen perlu meningkatkan strategi pemasaran dengan harapan adanya suatu kepuasan terhadap konsumen yang akhirnya akan mempengaruhi perilaku konsumen pasca pembelian. Menurut Cousins, Foskett dan Gillespie (2002) mengatakan alasan orang keluar makan adalah menginginkan kenyamanan, sesuatu hal yang barn selain makan di rumah, ingin dilayani. Pada tabel berikut ini disajikan alasan orang keluar makan (mengunjungi cafe) berdasarkan hasil pra penelitian yang dilaksanakan pada tamu yang berkunjung di Jubilare Dine and Wine Bandung. Pada tabel 1 tersebut terlihat bahwa 48\% alasan konsumen cafe (orang keluar makan) ialah mencoba makanan yang berbeda dengan di rumah. Hal tersebut menunjukan bahwa keputusan seseorang untuk mengunjungi cafe lebih didasarkan pada pengalaman apa yang akan mereka dapatkan. Wisata kuliner lebih dari sekedar mencicipi ataupun menikmati makanan barn nan eksotis.

Tabel 1

Alasan Orang Keluar Makan (Mengunjungi Café)

\begin{tabular}{|c|l|c|c|}
\hline \multirow{2}{*}{ No } & \multicolumn{1}{|c|}{ Alasan } & \multicolumn{2}{c|}{ Konsumen } \\
\cline { 3 - 4 } & & $\mathrm{F}$ & $\%$ \\
\hline 1 & $\begin{array}{l}\text { Ingin mencoba makanan yang } \\
\text { berbeda (wisata kuliner) }\end{array}$ & 24 & $48 \%$ \\
\hline 2 & Ada acara spesial / undangan & 6 & $12 \%$ \\
\hline 3 & Menginginkan kenyamanan / & 10 & $20 \%$ \\
\hline 4 & Tidak ada alasan khusus Jumlah & 10 & $20 \%$ \\
\hline \multicolumn{2}{|r}{ Sumber: data diolah (pra penelitian) 2014} & $100 \%$ \\
\hline
\end{tabular}

Kegiatan ini memerlukan pengerahan semua panca indra yang kita miliki seperti rasa, aroma, sentuhan, serta penglihatan. Konektivitas ini membidani lahirnya pengalaman dan sensasi tertentu yang hanya dapat dirasakan oleh penikmat (Virna:2007). Saat ini, makanan yang enak dan layanan yang memuaskan tidak lagi cukup bagi konsumen yang menginginkan pengalaman makan yang tak terlupakan saat makan di restoran atau cafe. Pengalaman makan di restoran atau cafe disebut meal experience. 
Menurut Cousins, Foskett dan Gillespie (2002) menyatakan bahwa variabel-variabel yang menjadi bagian dari produk restoran yang juga memengaruhi meal experience antara lain adalah food and drink (makanan dan minuman), atmosphere (suasana), cleanliness (kebersihan), level of service (tingkat layanan) dan price (harga). Mengenai motif - motif pcmbclian pelanggan cafe di Bandung secara umum didominasi oleh aspek produk, tampilan fisik yang menarik dan suasana yang merupakan elemen-elemen yang mdmbentuk meal experience yang diperolch oleh konsumen. Untuk menciptakan meal experience tersebut, cafe-cafe di Bandung tumbuh dengan berbagai konsep suasana untuk memenangkan hati konsumen serta profitabilitas perusahaan.

Kepuasan konsumen tercapai melalui komponen yang membentuk pengalaman yang bersifat menyeluruh, bukan parsial. Jadi, sukses sebuah cafe tidak hanya ditentukan oleh rasa makanan dan minumannya, melainkan juga kebersihan, layanan, suasana tempat, dan harga. Untuk itu, pemasar harus dapat mengemas elemen-elemen yang dapat dikontrol oleh pemasar berupa makanan dan minuman, kebersihan, layanan dan harga dengan baik sehingga dapat tcrcipta meal experience yang positif dan konsumen merasa puas. Tingkat kepuasan yang dirasakan konsumen dapat merupakan suatu rangsangan bagi perilaku konsumen pasca pembelian.

Konsumen yang merasa puas akan memperlihatkan peluang membeli yang lebih tinggi dalam kesempatan berikutnya. Konsumen yang merasa puas akan cenderung mengatakan sesuatu yang serba baik tentang produk yang bersangkutan kepada orang lain. Pemasaran sangat dekat dengan pengalaman konsumen yang terbentuk sewaktu bersentuhan dengan stimulus pemasaran. Pengalaman menikmati makanan di cafe dan di rumah adalah berbeda, dan pengalaman ini perlu diciptakan secara tepat bagi konsumen.

Hemmington (2007) menyatakan : "customers do not buy service delivery, they buy experiences; customers do not buy service quality, they buy memories; customers do not buy food and drink, they buy meal experiences; customers do not buy events or functons, they buy occasions ". Dengan begitu akan timbul rasa puas atau tidak puas konsumen yang akhirnya akan mempengaruhi perilaku pasca pembelian. Augustine Fou (2003) mengatakan bahwa : "Pengalaman akan produk lebih penting dari lainnya karena pelanggan berbicara antara satu dan lainnya. Jadi lainnya dapat mendengar dan belajar menjadi bagian yang sangat fundamental dari setiap marketing plan dan setiap marketing mix, terutama marketing memberikan pelanggan pengalaman terhadap produk dengan memberikan informasi yang lengkap untuk membuat keputusan pembelian dan perilaku pasca pembelian".

\section{B. METODE PENELITIAN}

Metode yang penyusun gunakan dalam penelitian kali ini adalah metode deskriptif dan verifikatif. Dengan menggunakan metode penelitian akan diketahui hubungan yang signifikan antara variabel yang diteliti sehingga menghasilkan kesimpulan yang akan memperjelas gambaran mengenai objek yang diteliti. Melalui jenis penelitian deskriptif maka penelitian ini bertujuan untuk memperoleh gambaran mengenai pengaruh yang ditimbulkan oleh meal experience yang diperoleh konsumen di Jubilare Dine \& Wine Bandung dalam menciptakan perilaku pasca pembelian. Sedangkan melalui penelitian verifikatif, akan diuji kebenaran dari suatu hipotesis yang dilaksanakan melalui pengumpulan data di lapangan. Dalam penelitian ini, diuji sejauhmana pengaruh yang ditimbulkan oleh meal experience yang diperoleh konsumen di Jubilare Dine \& Wine Bandung dalam menciptakan perilaku pasca pembelian.

Dalam penelitian ini yang menjadi objek penelitian berupa variabel bebas atau independent adalah meal experience yang terdiri dari makanan dan minuman (food and drink), suasana (atmosphere), 
kebersihan (cleanliness), tingkat layanan (level of service) dan harga (price) scdangkan variabel terikat atau variabel dependent adalah perilaku pasca pembelian pembelian. Populasi dalam penelitian ini adalah tamu yang pernah makan dan minum di Jubilare Dine \& Wine Bandung sehingga diketahui mengenai meal experience dan perilaku pasca. Populasi pada peneltian ini adalah konsumen dari bulan Januari — Juli 2014 sebanyak 4.877 orang (konsumen).

Dalam penclitian tidak mungkin semua populasi diteliti, hal ini disebabkan karena ketcrbatasan dana, tenaga, dan waktu. Pengambilan sampel ini harus dilakukan sedemikian rupa sehingga diperoleh sampel yang benar-benar berfungsi sebagai contoh atau dapat menggambarkan keadaan populasi yang sebenarnya. Peneliti menggunakan teknik sampling non-random yaitu accidental sampling. Teknik yang dipergunakan dalam menentukan besamya ukuran sampel yang diteliti salah satunya adalah dengan menggunakan rumus Slovin yaitu ukuran sampel merupakan perbandingan dari ukuran populasi dengan persentase kelonggaran ketidaktelitian, karena kesalahan dalam pengambilan sampel yang masih ditolerir atau diinginkan, maka taraf kesalahan yang ditetapkan adalah sebesar $10 \%$.

$$
\begin{aligned}
& n=\frac{n_{0}}{1+N e^{2}} \quad \text { Dimana: } \\
& \qquad \begin{array}{cl}
n & \text { ukuran sampel } \\
\mathrm{N} & =\text { ukuran populasi } \\
\mathrm{E} \quad & =\text { Kelonggaran ketidaktelitian karena kesalahan sampel yang dapat ditolerir }
\end{array} \\
& \text { (taraf kesalahan) }
\end{aligned}
$$

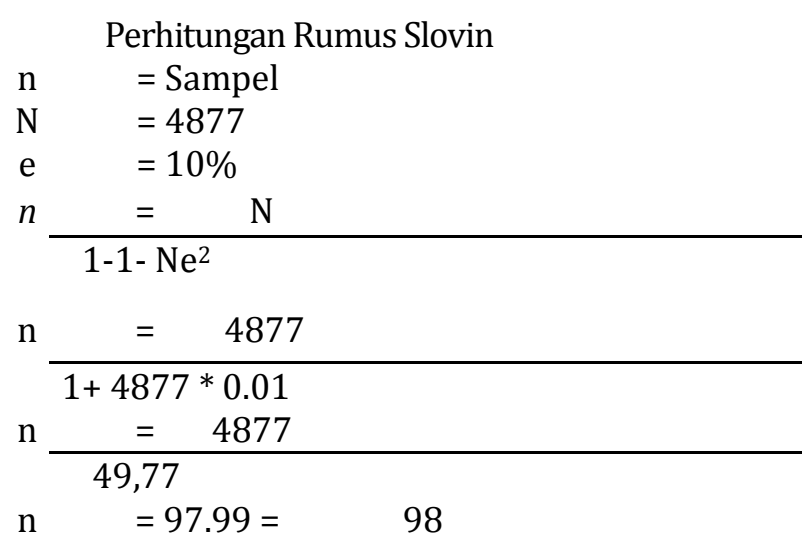

Berdasarkan perhitungan di atas dengan menggunakan rumus Slovin dengan tingkat kelonggaran sebesar 10\% maka diperoleh ukuran sampel (n) minimal sebesar 98, namun pada penelitian kali ini kuesioner yang akan disebar sebanyak 130 sebagai antisipasi apabila terdapat angket yang tidak layak untuk diolah dan untuk lebih memperoleh gambaran mengenai objek yang diteliti. Hal ini sesuai dengan pendapat Sekaran (2006) yang menyatakan semakin banyak sampel yang diteliti maka semakin valid atau representatif hasil yang diperoleh. Pengolahan penelitian ini menggunakan bantuan program SPSS (Statistical Product for Service Solution) 17.00 dan Ms. Office Excel 2007, dalam pengembangan dan pengujian model serta pengolahan data penelitian. 


\section{HASIL DAN ANALISIS}

Bilare Dine and Wine yang berlokasi di J1. Karangsari No.14 Merupakan salah satu restoran yang mempunyai konsep casual dining restoran yang didirikan pada tahun 2012 sebagai lokasi penelitian ini. Berdasarkan lembar kuesioner yang kami sebar sebanyak 130 lembar dalam kurun waktu 2 (dua) bulan yaitu pada tanggal 1 September - 31 Oktobcr 2014, telah terkumpul sebanyak 110 lembar kuesioner yang terisi dengan penuh.

Deskripsi karakteristik konsumen berdasarkan demografi meliputi jenis kelamin terdiri dari wanita 68 orang dan pria sebanyak 42 orang, untuk usia yang berusia dibawah 25 tahun sebanyak 39 orang, usia antara 25 hingga 40 tahun sebanyak 68 orang dan diatas 40 tahun sebanyak 3 orang. Pada tingkat pendidikan untuk jenjang SMU/Sederajat sebanyak 32 orang, pada pendidikan Diploma 1-3 sebanyak 17 orang, selanjutnya untuk jenjang S1/D4 sebanyak 45 orang dan terakhir pada jenjang pendidikan Pascasarjana 16 orang. Data responden berdasarkan pekerjaannya adalah sebagai berikut dengan pekerjaan pelajar/mahasiswa sebanyak 33 orang, wirausaha sebanyak 26 orang, pegawai swasta sebanyak 23 orang, pegawai negeri sebanyak 16 orang dan pekerjaan lainnya sebanyak 12 orang. Responden dengan ratarata penghasilan adalah sebagai berikut untuk yang dibawah satu juta sebanyak 16 orang, satu hingga tiga juta sebanyak 40 orang, tiga hingga lima hingga tujuh juta sebanyak 23 orang dan tidak ada responden yang menjawab berpenghasilan diatas tujuh juta.

Sedangkan berdasarkan pada jumlah kunjungan sebanyak 84 responden datang untuk yang kedua kalinnya dan 26 responden telah datang lebih dari dua kali. Lamanya responden berada di Jubilare Dine \& Wine Bandung yaitu antara 30 - 60 menit sebanyak 21 orang, satu hingga 2 jam sebanyak 66 orang dan lebih dari 3 jam sebanyak 23 orang. Jumlah pengeluaran responden setiap berkunjung adalah sebagai berikut dibawah 50 ribu ada sebanyak 13 orang, 50 ribu sampai 100 ribu sebanyak 38 orang, 100 ribu hingga 150 ribu sebanyak 24 orang clan tcrakhir diatas 150 ribu sebanyak 35 orang.

Selanjutnya pada tabel 2, terlihat bahwa berdasarkan alasan konsumen mengunjungi cafe, peringkat paling tinggi atau menjadi alasan utama adalah karena rasa makanan dan minuman yang ditawarkan dan juga suasana cafe atau restoran. Berikut merupakan hasil mengenai Pengalaman Konsumen di Jubilate Dine \& Wine Bandung berdasarkan alasan mengunjungi yang disajikan dalam bentuk tabel berikut ini.

Tabel 2

Alasan Berkunjung

\begin{tabular}{|c|c|c|c|c|c|c|c|}
\hline \multirow{2}{*}{$\begin{array}{c}\text { Alasan } \\
\text { Berkunjung }\end{array}$} & \multicolumn{2}{|c|}{ Tidak Baik } & \multicolumn{2}{|c|}{ Peingkat } & \multicolumn{2}{|c|}{ Sangat } & \multirow{2}{*}{ Total } \\
\hline & 1 & 2 & 3 & 4 & 5 & 6 & \\
\hline Rasa $F \& B$ & 0 & 34 & 19 & 4 & 41 & 12 & 110 \\
\hline Variasi & 15 & 9 & 42 & 34 & 9 & 1 & 110 \\
\hline Suasana & 14 & 38 & 20 & 21 & 17 & 0 & 110 \\
\hline Fasilitas & 19 & 13 & 19 & 24 & 13 & 22 & 110 \\
\hline Pelayanan & 0 & 4 & 2 & 17 & 64 & 23 & 110 \\
\hline & 2 & 8 & 12 & 21 & 28 & 39 & 110 \\
\hline
\end{tabular}

Sumber : Hasil Olahan Data Penulis 2014.

Sedangkan alasan yang tidak terlalu diperhitungkan oleh konsumen adalah harga. Hal ini patut dipahami karena bila konsumen merasa puas dengan pengalaman yang diperoleh dari makanan dan minuman yang ia konsumsi serta suasana yang ia rasakan, berapapun harga atau pengorbanan yang barns ia keluarkan tidak akan dipermasalahkan. Sclanjutnya terlihat bahwa berdasarkan peringkat yang diberikan oleh konsumen restoran I cafe secara berurutan yang menjadi alasan utama mereka makan diluar rumah adalah rasa yang ditawarkan, suasana, variasi menu, fasilitas yang ditawarkan, harga dan pclayanan. 
Perhitungan statistik yang didasarkan pada angka-angka dari masing-masing variabel terlebih dahulu dilakukan transformasi, diniana dalam perhitungan transformasi dilakukan dengan program yang ada dalam SPSS Versi 17.0. Secara lengkap basil pengolahan data pengaruh meal experience (pengalaman makan) beserta lima sub variabelnya terhadap penciptaan perilaku pasca pembelian konsumen di Jubilare Dine \& Wine Bandung disajikan secara rinci dalam Tabel 3 sebagai berikut:

Tabel 3.

Matriks Korelasi Antar Sub Variabel Meal Experience Terhadap Penciptaan Perilaku Pasca Pembelian

\begin{tabular}{|c|c|c|c|c|c|c|}
\hline & $\begin{array}{c}Y \\
\text { Meal } \\
\text { Experience }\end{array}$ & $\begin{array}{c}\text { X1.1 } \\
\text { Makanan \& } \\
\text { Minuman }\end{array}$ & $\begin{array}{c}\mathrm{X} 1.2 \\
\text { Suasana }\end{array}$ & $\begin{array}{c}\mathrm{X1.3} \\
\text { Kebersihan }\end{array}$ & $\begin{array}{c}\text { X1.4 } \\
\text { Tingkat } \\
\text { layanan }\end{array}$ & $\begin{array}{c}\text { X1.5 } \\
\text { Harga }\end{array}$ \\
\hline $\begin{array}{l}\text { YMeal } \\
\text { Experience }\end{array}$ & 1 & $.774 "$ & .683" & $.652 "$ & $.725 "$ & .751"" \\
\hline $\begin{array}{l}\text { X1.1 } \\
\text { Makanan \& } \\
\text { Minuman }\end{array}$ & .774"" & 1 & .595" & $.662 "$ & $.746 "$ & $.871 "$ \\
\hline $\begin{array}{l}\mathrm{X} 1.2 \\
\text { Suasana } \\
\end{array}$ & $.683 "$ & $.595 "$ & 1 & $.884 "$ & .603"'" & $.443^{\prime \prime "}$ \\
\hline Kebersihan & $.652 "$ & .662" ' & $.884 "$ & 1 & $.692 "$ & $.590 " "$ \\
\hline $\begin{array}{l}\text { X1.4 } \\
\text { Tingkat } \\
\text { Lavanan } \\
\end{array}$ & $.725 "$ & $.746 "$ & $.603 "$ & $.692 "$ & 1 & $.694^{* *}$ \\
\hline X1.5 Harga & .751" & .871" & $.443 "$ & $.590 "$ & .694" & 1 \\
\hline
\end{tabular}

Sumber : Hasil Olahan Data Penulis, 2014.

Berdasarkan basil matriks korelasi-antara sub variabel meal experience terhadap perilaku pasca pembelian diperoleh hasil korelasi secara berurutan yaitu, makanan dan minuman $(0,774)$, suasana $(0,683)$, kebersihan $(0,652)$, tingkat layanan $(0,725)$ dan harga $(0,751)$.

Pada Tabel 3 korelasi antara faktor-faktor meal experience yang diperoleh konsumen cafe dalam penciptaan perilaku pasca pembelian dapat dilihat bahwa menu makanan dan minuman berkorelasi positif terhadap perilaku pasca pembelian konsumen dengan korelasi sebesar 0,774. Koefisien tersebut menunjukkan bahwa antara makanan dan minuman dengan perilaku pasca pembelian memiliki hubungan yang kuat, sedangkan korelasi terbesar antara variabel X adalah suasana dan kebersihan yaitu sebesar 0,884 . Koefisien tersebut menunjukkan bahwa antara suasana dan kebersihan memiliki hubungan yang sangat kuat. Hasil matriks pada tabel 3 diketahui korelasi terendah antara variabel $\mathrm{X}$ dan variabel $\mathrm{Y}$ adalah kebersihan $(0,652)$, sedangkan korelasi terendah antara variabel $\mathrm{X}$ adalah harga dengan suasana sebesar 0,443 .

Pada Tabel 4 ditunjukan pengaruh meal experience terhadap perilaku pasca pembelian memiliki hubungan yang sangat kuat yakni dengan koefisien korelasi sebesar 0 .

Tabel 4

Output Koefisien Regresi

\begin{tabular}{|l|c|c|c|r|r|}
\hline \multirow{2}{*}{ Model } & \multicolumn{2}{|c|}{$\begin{array}{c}\text { Unstandardized } \\
\text { Coefficients }\end{array}$} & $\begin{array}{c}\text { Standardized } \\
\text { Coefficients }\end{array}$ & $\mathrm{t}$ & Sig. \\
\cline { 2 - 6 } & $\mathrm{B}$ & Std. Error & Beta & & \\
\hline 1 (Constant) & 2.149 & 2.271 & & .946 & .346 \\
\hline X 1 : Makanan \& Minuman & .056 & .182 & .035 & .308 & .759 \\
\hline X2 : Suasana & .929 & .149 & .686 & 6.222 & .000 \\
\hline X3 : Kebersihan & .816 & .218 & .445 & -3.735 & .000 \\
\hline
\end{tabular}




\begin{tabular}{|l|c|c|c|r|l|}
\hline X4 : Pelayanan & .294 & .099 & .234 & 2.974 & .004 \\
\hline X5 : Harga & 1.030 & .211 & .517 & 4.888 & .000 \\
\hline
\end{tabular}

Dependent Variable: (meal experience)

Pengujian hipotesis melalui nilai signifikasi dan uji-t menghasilkan penolakan terhadap Ho dan penerimaan Ho, karena nilai signifikasi ada yang lebih kecil dan besar dibandingkan dengan 0,05. Hal tersebut berarti bahwa terdapat pengaruh yang signifikan antara pengaruh meal experience yang terdiri dari suasana (X1.2), kebersihan (X1.3), tingkat layanan (X1.4) dan harga (X1.5). Namun untuk variabel makanan dan minuman (X1.1) dan kebersihan (X1.3), tidak berpengaruh secara signifikan terhadap perilaku pasca pembelian.

Pada Tabel 5 ditunjukan pengaruh meal experience terhadap perilaku pasca pembclian memiliki hubungan yang sangat kuat yakni dengan koefisien korelasi sebesar 0,764 hal ini menunjukan bahwa meal experience mampu membcrikan kontribusi positif maka perilaku pasca pembelian akan cenderung bernilai positif pula.

Tabel 5

koefisien korelasi

\begin{tabular}{|c|c|c|c|c|}
\hline Model & $\mathrm{R}$ & R Square & Adjusted R Square & Std. Error of the Estimate \\
\hline & $.874^{3}$ & .764 & .753 & 2.60746 \\
\hline
\end{tabular}

Predictors: (Constant), X5, X2, X4, X1 X3

Dependent Variabel : Y

Berdasarkan hasil korelasi selanjutnya akan dilakukan uji $\mathrm{F}$ untuk mengetahui hasil hipotesis. Besarnya nilai korelasi di atas dibuktikan dengan penolakan Ho yang dilakukan dengan uji $\mathrm{F}$ tingkat signifikasi (sig) sama dengan 0,000 atau lebih kecil dari 0,05. Hasil perhitungan Koefisien determinasi (R kuadrat) yang dinyatakan dalam persentase mengambarkan besarnya kontribusi semua variabel bebas yaitu sebesar 0,764 sedangkan koefisien jalur variabel lain di luar variabel meal experience. Hal tersebut menunjukkan bahwa faktor-faktor meal experience yang diperoleh konsumen cafe secara bersama-sama mempengaruhi perilaku pasca pembelian sebesar $76,4 \%$ dan sisanya sebesar $23,6 \%$ dipengaruhi faktor lain yang tidak masuk ke dalam penelitian ini.

\section{SIMPULAN}

If real Experience cafe di Jubilare Dine \& Wine Bandung menunjukkan bahwa pada dimensi makanan dan minuman ternyata signifikan dalam memberikan pengalaman yang berkesan pada konsumen walaupun secara korelasi dimensi makanan dan minuman memiliki korelasi yang cukup kuat terhadap perilaku pasca pembelian. Hal ini diduga karena pada industri jasa boga berjenis café, lebih dikenal sebagai tempat untuk berkumpul, bersantai dan mengobrol. Pada dimensi suasana, yang paling menggugah perasaan pelanggan adalah dekorasi (eksterior dan interior) serta alunan musik yang diputar di cafe tersebut. Pada dimensi kebersihan, yang mendapatkan penilaian yang baik dari konsumen adalah keseluruhan pengalaman yang dirasakan terhadap kebersihan di cafe tersebut. Pada dimensi tingkat layanan, yang paling menggugah perasaan konsumen adalah keramahan pelayan. Pelayanan karyawan café melalui kecepatan, ketepatan, dan keramahan karyawan dalam melayani pelanggan. Pada dimensi harga penilaian atas value for money yang konsumen rasakan ternyata yang mendapatkan kesesuaian antara pengorbanan yang konsumen keluarkan dengan kualitas dari makanan dan minuman yang konsumen terima. Secara keseluruhan, diantara seluruh faktor pencipta meal experience, faktor mendapatkan penilai tertinggi dari konsumen karena dirasakan mampu memberikan pengalaman yang memorable adalah makanan dan minuman. 
Perilaku pasca pembelian konsumen Jubilare Dine \& Wine Bandung yang diukur melalui persepektif kepuasan pasca pembelian menunjukan bahwa konsumen merasakan pengalaman makan yang menyenangkan dan merasa puas atas kualitas makanan dan minuman yang disajkan. Berdasarkan pada tindakan pasca pembelian, perilaku pasca pemebelian yang dapat dilakukan oleh konsumen adalah menceritakan hal-hal positif mengenai tempat ini pada orang lain.

Seclangkan berdasarkan tindakan digunakan atau tidak sebuah produk pasca pembelian, perilaku pasca pembelian yang akan dilakunan oleh konsumen adalah selalu mempertimbangkan cafe yang pernah ia kunjungi sebagai pilihan utama saat hendak melakukan kegiatan wisata kuliner atau makan diluar. Secara keseluruhan perilaku konsumen pasca pembelian yang mendapatkan penilaian tertinggi dari konsumen adalah kepuasan pasca pembelian yang mereka rasakan.

Meal experience berpengaruh positif terhadap perilaku konsumen pasca pembelian. Hasil ini menunjukkan bahwa semakin tinggi pelaksanaan meal experience maka semakin tinggi pula perilaku konsumen pasca pembelian.

\section{DAFTAR REFERENSI}

Augustine Fou., 2003. Experiential Marketing: Marketing Science Consulting Group, Inc. Back to Marketing Science Consulting Group - Digital Strategy Consulting. http://www.mktsci.com/experiential-marketing.htm Diunduh 1 Agustus 2014

Cousins, J., Foskett, D., \& Gillespie, C., 2002. Food and Beverage Management Second Edition. Prentice Hall

Ervi Virna:2007. Wisata Kuliner, Bukan Sekedar Wisata Pemuas Nafsu Perut. www.p2par.itb.ac.id/wp-content/uploads/2009/01/maret2007.pdf Diunduh 1 Agustus 2014

Husein, Umar 2003. Metode Riset Bisnis. Jakarta. Gramedia Pustaka Utama

Mashuri dan M. Zainudin. (2009). Metodologi Penelitian: Pendekatan Praktis dan Aplikatif. Bandung: Refika Aditama.

Professor- Nigel Hemminglon, 2008. From Service to Experience; understanding the role of people in the tourism business Caribbean Tourism Human Resources ThinkTank:,http://webcache.googleusercoritent.com/ search?g= cache: QEGDpyTk9FcPubtps: //www. 011ecaribbean.org/content/files/

NHemmingtonPresentation.pdf $+\& \mathrm{~cd}=1$ \&h1=id\&ct=clnk\&gl=id Diunduh 1 Agustus 2014 Smith, Shaun \& Wheeler, Joe. 2002. Managing The Customer Experience. Prentice hall.

Sugiyono. 2010. Metode Penelitian Bisnis. Bandung. Alfabeta

Uma Sekaran. 2006. Metode Penelitian Bisnis. Jakarta: Salemba Empat. 